\title{
Female Sexual Function as a Predictor of Well-Being
}

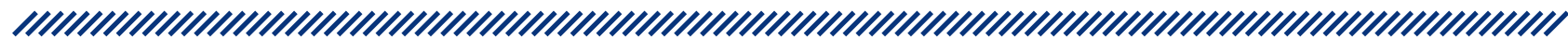

1 Andrej Starc

2 Borut Poljšak

3 Raja Dahmane

4 Tina Levec

5 Mitja Perat

1 University of Ljubljana, Faculty of Health Sciences, Chair of Public Health, Laboratory for Oxidative Stress Research, Ljubljana, Slovenia

2 University of Ljubljana, Faculty of Health Sciences, Laboratory for Oxidative Stress Research, Ljubljana, Slovenia

3 University of Ljubljana, Faculty of Health Sciences, Chair of Biomedicine in Health Care Division, Ljubljana, Slovenia

4 University of Ljubljana, Faculty of Health Sciences, Prosthetics Department; Orthotics and Prosthetics Division, Ljubljana, Slovenia

5 Institute for Human Resource Development, Ljubljana, Slovenia

\section{Abstract}

Introduction: The purpose of this study was to evaluate the relationship between the WHO-5 Well-Being Index and variables from the Female Sexual Function Index (FSFI) in a large-scale sample of partnered and single women.

Methods: Based on the Kolmogorov-Smirnov and Shapiro-Wilk test on six claims of FSFI, a non-parametric statistical analysis was used.
Results: Statistical significance was set at $p<0.05$. The sample included 635 female participants, aged 18 to 89 years. There was a strong link between all the six FSFI claims with marital status and number of sexual partners. The group of women who were involved in sexual intercourse in the previous 4 weeks shows higher life satisfaction $(n=366$; $50-100 \%$ ) compared to the group ( $n=37 ; 0-49 \%$ ) who were not involved in sexual intercourse in the previous 4 weeks. Even though the frequency of sexual functioning according to FSFI scores did not differ between the two groups $\left(\chi^{2}\right.$ $(1)=0.101, p=0.750)$, they did differ in the quality of sexual experience.

Conclusions: These results extend previous findings by confirming a strong relationship between sexual well-being and overall life satisfaction within individuals. They confirm the importance of sexual satisfaction in shaping the overall quality of life not only for men but also for women.

Keywords: female sexual response, dysfunction, desire, women's health, women's sexuality.

Article received: 15.3.2019.

Article accepted: 1.7.2019.

DOI: $10.24141 / 1 / 5 / 2 / 7$

\section{Corresponding author:}

Asst. Prof. Andrej Starc, PhD, BSc, BSc

A: University of Ljubljana, Faculty of Health Sciences, Chair of Public Health, Laboratory for Oxidative Stress Research Zdravstvena pot 5, 1000 Ljubljana, Slovenia

T: +386 $13001111 \mathrm{~F}:+35613001119$

E-mail: andrej.starc@guest.arnes.si 


\section{Introduction}

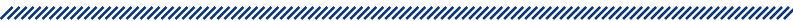

Female sexual dysfunction (FSD) (difficulties with sexual desire, arousal, lubrication, orgasm, satisfaction and pain) is very common in Slovenia (1-3) and around the world (4-6) with prevalence rates up to $31 \%$ in Slovenia (1-3), ranging from 32 to $85 \%$ in the United States (7), and up to $30 \%$ in Asia (Hong Kong, China, Korea, Taiwan and Singapore) (5). These studies have focused on sexual dysfunction $(1,5,6)$, or have described changes in various measures of sexual function in relation to pharmacological agents, pathological processes, or therapeutic agents aimed at curing sexual dysfunction (8), rather than explore sexual function in women who self-identify as being satisfied or dissatisfied with their sexual well-being.

Sexual function is strongly associated with mental health, relational satisfaction, and overall quality of life. Nevertheless, little is known about the relationship between perceived satisfaction with sexual function and well-being. Certain recent studies have provided empirical evidence of an association between sexual satisfaction and the quality of the overall well-being. Some authors explored the association between sexual and life satisfaction, in their results, sexual well-being was related to life satisfaction both cross-sectionally and within individuals over time (9).

However, the definition of female sexual satisfaction remains ambiguous; researchers have conceptualised overall sexual satisfaction as a psychological concept appraising contentment with one's overall sexual life. Consequently, the operationalisation of sexual satisfaction is often unpredictable across studies, and there is difficulty generalising research results (10).

At the Conference on Female Sexual Function Disorders, held in 1999 by the Sexual Function Health Council of the American Foundation for Urologic Disease, it was proposed that sexual satisfaction disorder be added as a new diagnostic category for sexual dysfunction in the Diagnostic and Statistical Manual of Mental Disorders, Fourth Edition. However, since they noted a lack of epidemiological evidence or objective criteria for the diagnosis of such category, the proposal was not adopted. Nevertheless, the conference highlighted the importance of determining the objective predictors of women's sexual satisfaction (11).

The World Health Organization (12) developed the WellBeing Index (WHO-5) that was a short self-reported measure of current mental wellbeing, and that could be used quickly by the patient (13). The first version of the Well-Being Index consisted of 28 items (14). Finally, a reviewed version was proposed in 1998 by the WHO (12) and used throughout the world to investigate the objective indicators of well-being (15-17).

The WHO- 5 consists of five statements about mental well-being, which respondents rate according to the scale below (in relation to the past two weeks).

- All of the time $=5$

- Most of the time=4

- More than half of the time=3

- Less than half of the time $=2$

- Some of the time=1

- At no time $=0$.

The goal of the present study was to improve the scientific understanding of the link between sexual and life satisfaction in women by exploring the factor structure of women's causal attributions regarding their sexual function and the relationship between these attributions and multiple indicators of well-being. Consequently, the relationship of the WHO-5 Well-Being Index with demographic variables from the female sexual function index (FSFI) (18) will be analysed in a large-scale sample of partnered and single women.

\section{Methodology}

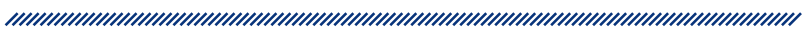

\subsection{Participants and Procedure}

The research was conducted on female participants via online survey. The investigations were conducted according to the Declaration of Helsinki principles. The online survey started in June and was concluded in September 2016.

\subsection{Data Collection}

The online survey started in June and was concluded in September 2016. A combination of the validated standardised FSFI questionnaire and demographic data was used. 
One thousand and five hundred female participants received an invitation to participate in the online survey. The recruitment process was based on the following inclusion conditions: (a) adulthood (age18 $\geq$ years); (b) understanding the written explanation; and (c) the online return of questionnaire being understood as consent. Of the 1500 invitations, the final sample included 635 female participants; the realisation of the sample was $42.3 \%$. The Cronbach alpha coefficient showed an appropriate internal consistency for each claim of the FSFI questionnaire (desire, arousal, lubrication, orgasm, satisfaction, and pain), and the WHO-5 Well-Being Index questionnaire. We divided the sample in the WHO-5 WellBeing Index into two groups: Group No. 1 (low life satisfaction from 0 to 49\%), and Group No. 2 (high life satisfaction from 50 to 100\%). We compared the FSFI factors between the low and high WHO-5 groups (Table 1 ).

All participants were asked about their demographic variables, including age, marital status, religion, sexual orientation, and number of sexual partners in the last year. For FSFI, a validated questionnaire with 19 multiple-choice questions on a 5- or 6-point Likert scale was used. Domain scores were calculated by totalling the responses to items in each domain, followed by scaling this total with a multiplier that contains all domains of the same range. Linguistic validation of the questionnaire was performed based on a translation from English to Slovenian language and vice versa. SPSS 27.0 statistical software was used. The Kolmogorov-Smirnov and Shapiro-Wilk tests were applied to six claims of FSFI. Based on these findings, a non-parametric statistical analysis with the Spearman correlation coefficient and $\chi 2$ - test were used. Statistical significance was set at $p<0.05$.

In Table 1, the internal consistency of claims is presented. For all the FSFI claims, the internal consistency was very high $(\alpha=0.980)$ and also for the WHO-5 claims $(\alpha=0.874)$.

\begin{tabular}{|c|c|c|c|}
\hline \multicolumn{4}{|c|}{ Table 1. Internal consistency of claims } \\
\hline Claim & Questions & Likert scale & $(\alpha)$ \\
\hline Desire & 1,2 & $1-5$ & 0.875 \\
\hline Arousal & $3,4,5,6$ & $0-5$ & 0.973 \\
\hline Lubrication & $7,8,9,10$ & $0-5$ & 0.974 \\
\hline Orgasm & $11,12,13$ & $0-5$ & 0.966 \\
\hline Satisfaction & $14,15,16$ & 0 (or 1 ) -5 & 0.956 \\
\hline Pain & $17,18,19$ & 0 (or 1 ) -5 & 0.969 \\
\hline All FSFI & & & 0.980 \\
\hline All WHO-5 & & $1-5$ & 0.874 \\
\hline
\end{tabular}

\section{Results}

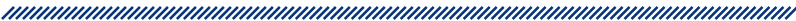

The sample included 635 female participants, aged from 18 to 89 years. They were mostly young, 20 years $(n=122 ; 19.2 \%), 21$ and 22 years $(106 ; 16.75 \%)$ and 19 years $(n=40 ; 6.3 \%)$.

Most of the participants were still students $(n=262$; $41.3 \%)$, had concluded secondary ( $n=219 ; 34.5 \%), 1$ st degree $(n=111 ; 17.5 \%)$, 2nd degree $(n=25 ; 4 \%)$, postsecondary $(n=10 ; 1.6 \%)$, and elementary education $(n=3 ; 0.5 \%)$. Five participants did not answer $(p=0.000$; $\chi^{2}=1220.286 ; M=6.400 ; S D=3.1601$ ).

In the sample, most of the participants were in a relationship (not married) $(394 ; 62 \%)$, single (never married) $(n=201 ; 31.7 \%)$, married $(n=35 ; 5.5 \%)$, separated $(n=3$; $0.5 \%)$, and widowed $(n=2 ; 0.3 \%)\left(p=0.000 ; \chi^{2}=1220.286\right.$; $\mathrm{M}=3.557 ; \mathrm{SD}=1.8715$ ).

Most of the participants ( $n=391 ; 61.6 \%$ ) were Catholics, 24 Orthodox (3.8\%), 21 Muslim (3.3\%), 5 Other Christian $(0.8 \%)$, and one Evangelist $(0.2 \%)$. One hundred and four declared themselves to be atheists (16.4\%), 20 did not want to answer (3.1\%), and three declared themselves believers but not belonging to any religion (9.9\%) (Table 2).

\begin{tabular}{|c|c|c|}
\hline Table 2. Religion of the participants (n=629) \\
\hline & $\mathrm{f}$ & $\%$ \\
\hline Catholic & 391 & 61.6 \\
\hline Evangelical & 1 & 0.2 \\
\hline Orthodox & 24 & 3.8 \\
\hline Other Christian & 5 & 0.8 \\
\hline Muslim & 21 & 3.3 \\
\hline Believer, but I do not belong to any religion & 63 & 9.9 \\
\hline I do not believe, atheist & 104 & 16.4 \\
\hline I do not want to answer & 20 & 3.1 \\
\hline Missing & 6 & 0.9 \\
\hline$p=0.000 ; \chi^{2}=1521.830 ;$ M=4.219; SD $=4.4122$ & & \\
\hline
\end{tabular}

In the sample most of the participants were heterosexual ( $n=586 ; 92.3 \%), 16(2.5 \%)$ bisexual, and 7 (1.1\%) homosexual (Table 3). 


\begin{tabular}{|c|c|c|}
\hline & $\mathrm{f}$ & $\%$ \\
\hline $\begin{array}{l}\text { Heterosexual relationship (sexual } \\
\text { intercourse with a person of the opposite } \\
\text { sex only) }\end{array}$ & 586 & 92.3 \\
\hline $\begin{array}{l}\text { Homosexual relationship (sexual } \\
\text { intercourse with a person of the same sex } \\
\text { only) }\end{array}$ & 7 & 1.1 \\
\hline $\begin{array}{l}\text { Bisexual relationship (sexual intercourse } \\
\text { with persons of the opposite sex and the } \\
\text { same sex) }\end{array}$ & 16 & 2.5 \\
\hline Missing & 26 & 4.1 \\
\hline \multicolumn{3}{|l|}{$p=0.000 ; \chi^{2}=1084.108 ; M=1.064 ; S D=0.3357$} \\
\hline
\end{tabular}

In the previous year, the participants were involved in sexual activities with various numbers of partners. Most of the participants were involved in sexual intercourse with one $(n=437 ; 68.8 \%)$, two $(n=53 ; 8.3 \%)$, three $(n=17$; $2.7 \%)$, four $(n=8 ; 1.3 \%)$, five $(n=5 ; 0.8 \%)$, from ten to twenty-two partners ( $n=3 ; 0.6 \%)$. Eighty-six were not involved in sexual activities (13.5\%), and 26 (4.1\%) did not answer (Table 4).

\begin{tabular}{|c|c|c|}
$\begin{array}{c}\text { Table 4. Number of sexual partners of the } \\
\text { participants (n=609) }\end{array}$ \\
\hline & $\mathrm{f}$ & $\%$ \\
\hline 0 & 86 & 13.5 \\
\hline 1 & 437 & 68.8 \\
\hline 2 & 53 & 8.3 \\
\hline 3 & 17 & 2.7 \\
\hline 4 & 8 & 1.3 \\
\hline$p=0.000 ; \chi^{2}=2369.645 ; \mathrm{M}=1.144 ; \mathrm{SD}=1.3062$ & \\
\hline
\end{tabular}

The Spearman's rho correlation was found to be positive between different FSFI claims (Table 5) The highest was between arousal and lubrication (0.771) and between orgasm and satisfaction (0.689):

- desire and arousal, lubrication, satisfaction, pain, orgasm, and marital status;

- arousal and lubrication, satisfaction, orgasm, pain, and marital status;

- lubrication and satisfaction, orgasm, pain, and marital status;

- orgasm and satisfaction, pain, and marital status;

- satisfaction, pain, and marital status.

Correlations between other demographic variables were not found.

In the contingency Table 6, two groups show significant differences linked to well-being. The group of women who were involved in sexual intercourse in the previous 4 weeks shows higher life satisfaction $(n=366 ; 50-100 \%)$ compared to the group ( $n=37 ; 0-49 \%)$ who were not involved in sexual intercourse in the previous 4 weeks.

Table 6. Frequencies of sexual activity
involvement between high and low WHO-5
groups

\begin{tabular}{|c|c|c|c|c|c|c|c|}
\hline \multicolumn{7}{|c|}{ Table 5. Correlation between FSFI claims } \\
\hline & Desire & Arousal & Lubrication & Orgasm & Satisfaction & Pain & Marital status \\
\hline Desire & & $.565^{* *}$ & $.436^{* *}$ & $.318^{* *}$ & $.409^{* *}$ & $.326^{* *}$ & $.118^{*}$ \\
\hline Arousal & $.565^{* *}$ & & $.771^{* *}$ & $.713^{* *}$ & $.720^{* *}$ & $.641^{* *}$ & $.352^{* *}$ \\
\hline Lubrication & $.436^{* *}$ & $.771^{* *}$ & & $.650^{* *}$ & $.659^{* *}$ & $.618^{* *}$ & $.295^{\star *}$ \\
\hline Orgasm & $.318^{* *}$ & $.713^{* *}$ & $.650^{* *}$ & & $.689^{* *}$ & $.531^{* *}$ & $.296^{* *}$ \\
\hline Satisfaction & $.409^{* *}$ & $.720^{* *}$ & $.659^{* *}$ & $.689^{* *}$ & & $.581^{* *}$ & $.431^{\star *}$ \\
\hline Pain & $.326^{* *}$ & $.641^{* *}$ & $.618^{* *}$ & $.531^{* *}$ & $.581^{* *}$ & $.371^{* *}$ \\
\hline Legend: ${ }^{* *}<0.05, * * p<0.01$ & & & & & \\
\hline
\end{tabular}


In the sample, the low and high life satisfaction in the past four weeks within FSFI claims was checked. The group of high life satisfaction showed statistically significantly higher scores on all FSFI claims compared to the group with low life satisfaction (Table 7).

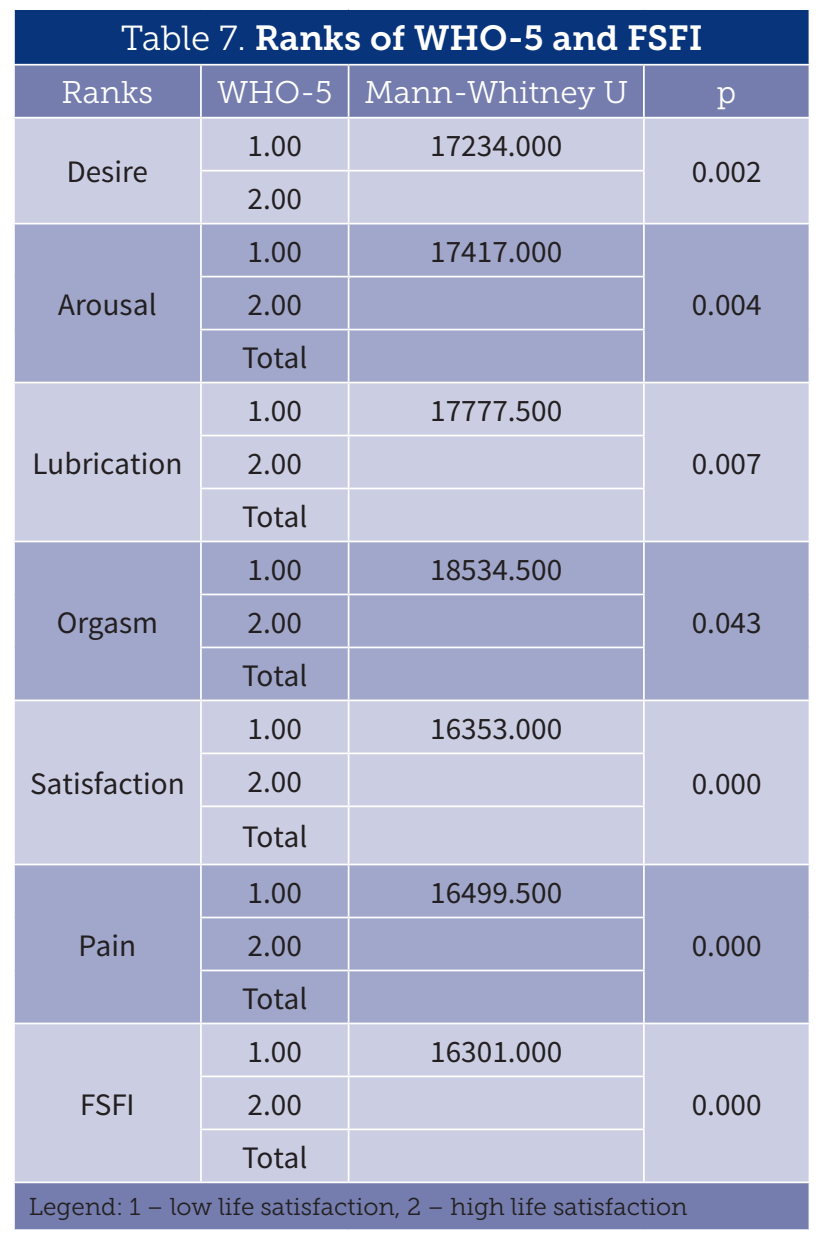

\section{Conclusions}

In a large-scale sample, we aimed to explore differences in the sexual function index (FSFI) and well-being among different groups of women with low and high life satisfaction (WHO-5 Well-Being Index). We compared differences between the low and high life satisfaction in the previous four weeks within FSFI claims. The group with high life satisfaction showed statistically significantly higher scores on all FSFI claims compared to the group with low life satisfaction (Table 7). Even though the fre- quency of sexual functioning according to FSFI scores did not differ between the two groups $\left(\chi^{2}(1)=0.101\right.$, $p=0.750$ ), the groups did differ in the quality of sexual experience. The low WHO-5 group showed less sexual satisfaction than the high (Table 7) WHO-5 group.

Similar results of a large-scale survey carried out by the American Association of Retired Persons found that between $55 \%$ and $60 \%$ of Americans aged 45 years and older believed that sexual activity was an essential element of a satisfactory relationship and quality of life for older adults (19-20).

In women, depression is often linked to different reproductive and sexual outcomes, such as miscarriage and menopause (21). In other words, the depressive mood among women increased as a function of the elapsed time since their last sexual intercourse. This claim is confirmed by the high correlation we found between satisfaction and marital status, for which the sexual activity is safe and regular. Women in marital status do not use condoms, Ney (22) hypothesised that semen absorbed through the vagina might have an effect on mood in women. Hormones in seminal liquid include testosterone, oestrogen, follicle-stimulating hormone and luteinising hormone, prolactin, and a number of different prostaglandins. Many of these antidepressant compounds present in human semen can be absorbed quickly through the vagina and can be detected in the bloodstream within a few hours of absorbtion.

Although a certain number of studies have suggested a correlation between sexual activity and life satisfaction, ours is one of the rare ones to examine this relation in a sample of women presenting a large range of sexual claims (desire, arousal, lubrication, orgasm, satisfaction, and pain) (23).

Despite some limitations, our findings have a practical consequence. They confirm the importance of sexual satisfaction in shaping the overall quality of life not only for men but also for women. They also show that the importance of sexual satisfaction may rival factors such as attachment orientation that have been the subject of constant research interest in recent decades.

\subsection{Limitations}

The strength of our correlation study is moderated by some limitations:

- Although we used a well-validated questionnaire, self-report scales come with a number of deficiencies including possible social desirability bias. 
In addition, the sample was restricted in a number of ways, including a large number of young women, and not enough older women.

It is important to acknowledge that our results are correlational in nature and, as such, are only suggestive.

Another potentially biasing factor was that participants were recruited through an online survey. As such, although some part of the sample met the full criteria for sexual dysfunction, these women cannot be described as seeking treatment.

\section{References}

1. Starc A, Jukić, T, Poljšak, B, Dahmane, R. Female sexual function and dysfunction: a cross national prevalence study in Slovenia. Acta Clin Croat. 2018; 57(1): 52 - 60. doi: 10.20471/acc.2018.57.01.06.

2. Božič, M. (2018). The prevalence of female sexual dysfunction in Slovenia: master thesis: Ljubljana.

3. Starc A, Perat, M, Poljšak, B, Dahmane R. Female sexual function and dysfunction: national prevalence study in Slovenia. Klinička psihologija. 2016; 9(1): 91. doi: 10.21465/2016-KP-OP-0040.

4. Forbes MK, Baillie AJ, Schniering CA. Critical flaws in the Female Sexual Function Index and the International Index of Erectile Function. J Sex Res. 2014; 51(5): 485 - 91. doi: 10.1080/00224499.2014.894491.

5. Nicolosi A, Laumann EO, Glasser DB, Moreira ED Jr., Paik A, Ginell C. Sexual behavior and sexual dysfunctions after age 40: the global study of sexual attitudes and behaviors. J Urol. 2004; 64(5): 991 - 97.

6. Rosen RC, Taylor JF, Leiblum SR, Bachmann GA. Prevalence of sexual dysfunction in women. Results of a survey study of 329 women in an outpatient gynecological clinic. J Sex Marital Ther. 1993; 19: 171 - 88.

7. Hayes RD, Dennerstein L, Bennett CM, Sidat M, Gurrin LC, Fairley CK. Risk factors for female sexual dysfunction in the general population: Exploring factors associated with low sexual function and sexual distress. J Sex Med. 2008; 5: 1681 - 693. doi:10.1111/j.1743-6109.2008.00838.x.

8. Shifren JL, Braunstein GD, Simon JA, Casson PR, Buster JE, Redmond GP, et all. Transdermal testosterone treatment in women with impaired sexual function after oophorectomy. N Engl J Med. 2000; 343: 682 - 8.

9. Stephenson KR, Meston CM (2015a). The conditional importance of sex: exploring the association between sexu- al well-being and life satisfaction. J Sex Marital Ther. 2015; 41: 25 - 38. doi:10.1080/0092623X.2013.811450

10. Dundon CM, Rellini AH. More than sexual function: predictors of sexual satisfaction in a sample of women age 40 - 70. J Sex Med. 2010; 7: 896 - 04. doi: 10.1111/j.17436109.2009.01557.x

11. Basson R, Berman J, Burnett A, Derogatis L, Ferguson D, Fourcroy J, et al. Report of the International consensus development conference on female sexual dysfunction: definitions and classifications. J Sex Marital Ther. 2001; 27: $83-94$.

12. World Health Organization. Info package: mastering depression in primary care. World Health Organization: Regional Office for Europe, Psychiatric Research Unit. Frederiksborg, 1988

13. Heun R, Burkart M, Maier W, Bech P. Internal and external validity of the WHO Well-Being Scale in the elderly general population. Acta Psychiatr Scand. 1999; 99: $171-78$.

14. Bradley C. Handbook of psychology and diabetes: a guide to psychological measurement in diabetes research and practice. London: Harwood, 1994

15. Topp CW, Ostergaard SD, Sondergaard S, Bech P. The WHO-5 Well-Being Index: a systematic review of the literature. Psychother Psychosom. 2015; 84: 167 - 76. doi: 10.1159/000376585.

16. Mortazavi F, Mousavi SA, Chaman R, Khosravi A. Validation of the World Health Organization-5 Well-Being Index; assessment of maternal well-being and its associated factors. Turk Psikiyatri Derg. 2015; 26: 48 - 55.

17. Love J, Andersson L, Moore CD, Hensing G. Psychometric analysis of the Swedish translation of the WHO well-being index. Qual Life Res. 2014; 23: 293 - 97. doi: 10.1007/ s11136-013-0447-0.

18. Rosen R, Brown C, Heiman J, Leiblum S, Meston C, Shabsigh $\mathrm{R}$, et al. The Female Sexual Function Index (FSFI): a multidimensional self-report instrument for the assessment of female sexual function. J Sex Marital Ther. 2000; 26: 191 - 08.

19. Lindau ST, Schumm LP, Laumann EO, Levinson W, O'Muircheartaigh CA, Waite LJ. A study of sexuality and health among older adults in the United States. N. Engl. J. Med. 2007; 357: 762 - 74. doi:10.1056/NEJMoa067423

20. AARP. Sexuality at midlife and beyond: 2004 Update of attitudes and behaviors. Accessed September 23th, 2018 at: http://assets.aarp.org/rgcenter/general/2004_sexuality.pdf.

21. Suarez, SD, Gallup GG, Jr. Depression as a response to reproductive failure. Journal of Social and Biological Structures. 1985; 8: $279-87$.

22. Ney PG. The intravaginal absorption of male generated hormones and their possible effect on female behavior. Med Hypotheses. 1986; 20: 221 - 31.

23. HinchliffS, Tetley J, Lee D, Nazroo J. Older adults' experiences of sexual difficulties: qualitative findings from the english longitudinal study on ageing (ELSA). J Sex Res. 2018; 55(2): 152 - 63. doi: 10.1080/00224499.2016.1269308. 


\section{ŽENSKA SEKSUALNA FUNKCIJA KAO PREDIKTOR OPĆE DOBROBITI}

1 Andrej Starc

2 Borut Poljšak

3 Raja Dahmane

4 Tina Levec

5 Mitja Perat

1 Univerza v Ljubljani, Zdravstvena fakulteta, Katedra za javno zdravje, Laboratorij za raziskovanje oksidativnega stresa, Ljubljana, Slovenija

2 Univerza v Ljubljani, Zdravstvena fakulteta, Laboratorij za raziskovanje oksidativnega stresa, Ljubljana, Slovenija

3 Univerza v Ljubljani, Zdravstvena fakulteta, Katedra za biomedicino v zdravstvu, Ljubljana, Slovenija

4 Univerza v Ljubljani, Zdravstvena fakulteta, Oddelek za protetiko; Katedra za ortotiko in protetiko, Ljubljana, Slovenija

5 Inštitut za razvoj človeških virov, Ljubljana, Slovenia tvrdnji Indeksa ženske seksualne funkcije s bračnim statusom i brojem seksualnih partnera. Grupa žena koje je imala spolne odnose u prethodna 4 tjedna pokazuje veće zadovoljstvo životom ( $\mathrm{n}=366 ; 50-100 \%)$ u odnosu na skupinu ( $n=37 ; 0-49 \%$ ) koja nije imala spolne odnose $u$ prethodna 4 tjedna. lako se učestalost seksualnog funkcioniranja prema rezultatima Indeksa nije razlikovala između dviju skupina $(\chi 2(1)=0,101, p=0,750)$, postojala je razlika u kvaliteti seksualnog iskustva.

Zaključci: Ovi rezultati proširuju prethodne rezultate potvrđujući snažnu vezu između seksualnog blagostanja i ukupnog zadovoljstva životom kod pojedinaca. Oni potvrđuju važnost seksualnog blagostanja u oblikovanju ukupne kvalitete života ne samo za muškarce, nego i za žene.

\section{Sažetak}

Uvod: Svrha ovog istraživanja bila je procijeniti odnos između WHO-5 indeksa blagostanja i varijabli iz Indeksa ženske seksualne funkcije (FSFI) na velikom uzorku žena s i bez partnera.

Metode: Na temelju Kolmogorov-Smirnov i Shapiro-Wilk testa na šest tvrdnji Indeksa ženske seksualne funkcije korištena je neparametarska statistička analiza.

Rezultati: Statistička značajnost je postavljena na $\mathrm{p}<0,05$. Uzorak je obuhvatio 635 ispitanica u dobi od 18 do 89 godina. Postojala je snažna veza između svih šest

Ključne riječi: ženska seksualna reakcija, disfunkcija, želja, žensko zdravlje, ženska seksualnost. 